\title{
Dermatologiczna choroba przewlekła jako czynnik ryzyka wykluczenia społecznego
}

\begin{abstract}
STRESZCZENIE
Celem artykułu jest przedstawienie problematyki jakości życia osób z przewlekłą chorobą dermatologiczną. W pierwszej części opracowania scharakteryzowano pojęcie choroby przewlekłej, ze szczególnym uwzględnieniem choroby dermatologicznej jako kategorii piętna powodującego marginalizację oraz wykluczenie społeczne. Część druga dotyczy jakości życia osób z chorobą dermatologiczną na płaszczyznach: fizycznej, psychicznej oraz społecznej. W części trzeciej opisano trudności terapeutyczne i funkcjonalne, których doświadczają osoby cierpiące na wybrane schorzenia dermatologiczne: atopowe zapalenie skóry, łysienie plackowate oraz łuszczycę. Zakończenie jest próbą wskazania przykładów działań pomocowych podejmowanych przez sektor pozarządowy na rzecz osób chorujących dermatologicznie.
\end{abstract}

\section{Słowa kluczowe:}

dermatologiczna choroba przewlekła, jakość życia, wykluczenie społeczne

\section{ABSTRACT}

The aim of the article is to present the problem of quality of life of people with chronic dermatological disease. In the first part of the study, the concept of chronic disease was characterized, with particular emphasis on dermatological disease as a category of stigma, resulting in marginaliza-

1 Magdalena Wałachowska, Wydział Nauk Pedagogicznych, Akademia Pedagogiki Specjalnej im. Marii Grzegorzewskiej w Warszawie, Polska, e-mail: mwalachowska@aps.edu.pl. 
tion and social exclusion. The second part deals with the quality of life of people with dermatological disease at the physical, psychological and social levels. The third part describes the therapeutic and functional difficulties of people suffering from selected dermatological diseases: atopic dermatitis, alopecia areata and psoriasis. The ending is an attempt to show examples of assistance activities undertaken by the non-governmental sector in favor of people suffering from dermatological diseases.

\section{Keywords:}

dermatological chronic disease, quality of life, social exclusion

\section{WSTĘP}

Jedną z chorób dermatologicznych najdłużej trwających w historii ludzkości jest trąd. Pierwsze zapiski na jego temat pochodzą z VII wieku p.n.e. z Indii. Obecnie również występuje głównie w Indiach, ale także w krajach Azji Południowo-Wschodniej, Afryki Równikowej oraz Ameryki Południowej. Jest to zakaźna dermatologiczna choroba przewlekła, która, atakując tkankę podskórną, prowadzi do nieodwracalnego inwalidztwa. Trąd nadal wzbudza lęk i odrazę, oznacza napiętnowanie, mimo iż jest to przypadłość dziś uleczalna, a chorujących skazuje na wykluczenie z życia społecznego i rodzinnego. Widoczne dla otoczenia rozległe rany, owrzodzenia i deformacje kości wzbudzają niechęć i odrazę obserwatorów (Pietras, Bogowska, 2017). Choć w Polsce ogniska trądu wygasły w XVII wieku, wokół nas żyje wielu ludzi tracących nadzieję z powodu różnorodnych opornych na leczenie, przewlekłych chorób dermatologicznych, które ciążą jako społeczne piętno, powodując wykluczenie z kontaktów towarzyskich, obszarów zawodowych i edukacyjnych, kanonów obyczajowych życia codziennego oraz usług.

\section{DERMATOLOGICZNA CHOROBA PRZEWLEKŁA - PIĘTNO, MARGINALIZACJA, WYKLUCZENIE SPOŁECZNE}

Choroba przewlekła jest przypadłością o długim czasie trwania (World Health Organization, 2014). Cechuje ją polietiologia, a więc brak jednej określonej przyczyny. Powoduje nieodwracalne zmiany patologiczne w organizmie, które mogą prowadzić do niepełnosprawności i śmierci. Rozwija się powoli - początek bywa trudny do uchwycenia, a moment zakończenia jest nieprzewidywalny lub może nigdy nie nastąpić. Choroba przewlekła przebiega z okresami remisji i nawrotów, na które przypada czas najintensywniejszego leczenia. Jego celem jest zatrzy- 
mywanie postępów choroby, ponieważ pełne wyleczenie jest niemożliwe (Ziarko, 2014). Choroby przewlekłe są jednymi z najpoważniejszych współczesnych problemów zdrowotnych społeczeństw krajów rozwiniętych, ponieważ stanowią główną przyczynę zgonów. Ich epidemia nastąpiła w XX wieku. Współcześnie najczęściej występującymi zaburzeniami przewlekłymi, które mogą prowadzić do śmierci, są: choroby serca, nowotwory, udary, przewlekłe choroby płuc, cukrzyca oraz choroby wątroby (Ziarko, 2014). Niemniejszym problemem zdrowotnym są choroby dermatologiczne. „Co trzeci dorosły Polak aktualnie choruje bądź chorował w przeszłości na choroby skóry, najczęściej z kręgu wyprysku oraz trądziku” (Śpiewak, 2012, s. 53). Najpowszechniejszymi zmianami chorobowymi były: wyprysk/zapalenie, trądzik, grzybica (skóra, paznokcie), pokrzywka, łuszczyca oraz skórne reakcje polekowe różnego typu. Brakuje aktualnych danych epidemiologicznych na temat występowania chorób skóry w populacji generalnej (Śpiewak, 2012). Lesław Grzegorczyk (1974), badając epidemiologię zawodowych chorób skóry w latach 70. XX wieku na przykładzie województwa rzeszowskiego, stwierdził, że stanowiły one 4-5\% czasowej niezdolności do pracy. Zwracał uwagę na błędy w zakresie zgłaszania i wykrywania tych schorzeń (około 70\% wszystkich chorób zawodowych skóry nie było zgłaszanych), a także tendencję pacjentów do nieleczenia zaburzeń dermatologicznych.

Skórną chorobę przewlekłą można utożsamić ze zjawiskiem piętna. Termin „piętno” został utworzony przez starożytnych Greków, którzy nazwali tym pojęciem znaki cielesne naznaczające osobę w sposób nadzwyczajny lub negatywny. Piętna wypalano lub wycinano na ciele, a oznaczały one niewolnictwo, nieczystość, zdradę lub skazę, od której należało stronić. Chrześcijaństwo uzupełniło znaczenie piętna o oznakę świętości i łaski (stygmaty), a medycyna o objaw zaburzeń fizycznych organizmu. Współcześnie „piętno” oznacza hańbę (Goffman, 2005), a „Napiętnowane osoby są spostrzegane jako niedoskonałe, upośledzone, jako istoty nie w pełni ludzkie” (Davidio, Major, Crocker, 2008, s. 25). Konsekwencją napiętnowania jest marginalizowanie, a więc uznanie osoby za kogoś, kto odbiega od społecznych oczekiwań uznawanych za normę. „Marginalizacja” to „utrata lub pomniejszenie znaczenia, pozycji, roli czegoś albo wpływu na coś” (Dubisz, 2003, s. 563). Niekorzystna pozycja osoby napiętnowanej, marginalizowanej popycha ją ku wykluczeniu społecznemu (Broda-Wysocki, 2012, s. 42-60), którego jedną z przyczyn jest niski status zdrowotny. Pierwszym badaczem, który formułując teorię piętna w 1963 roku, wyjaśnił zachowania i odczucia ludzkie wywoływane różnymi odstępstwami od ogólnie przyjętej normy był Erving Goffman. Według Goffmana (2005) zjawisko piętna powstaje na skutek zestawienia niekorzystnego atrybutu zewnętrznego lub wewnętrznego ze społecznie uznanym stereotypem, 
a więc kontekst społeczny oraz cechy otoczenia fizycznego mają wpływ na to, czy jakiś atrybut osoby jest piętnem, czy też nie². Przykładami negatywnych atrybutów zewnętrznych są widoczna niepełnosprawność, szpetne rysy, otyłość czy nieestetyczny ubiór. Mechanizm piętna związanego z chorobą lub niepełnosprawnością powstaje w następujący sposób: pojawienie się negatywnego atrybutu w postaci objawów choroby; niekorzystny odbiór społeczny tych objawów (wstręt, odraza, lęk); skojarzenie nieprzyjemnego objawu z powszechnie uznanym stereotypem (Rzepa, 2011).

Choroby dermatologiczne sprzyjają napiętnowaniu, gdyż wywołują przykre objawy, wzbudzające w obserwatorach negatywne emocje. Na osobach chorujących ciąży stereotyp niehigienicznego trybu życia (złe odżywianie się, stosowanie używek, zaniedbywanie higieny osobistej, słabe radzenie sobie ze stresem). Postawa osób zdrowych w stosunku do chorych dermatologicznie może być usprawiedliwiająca lub piętnująca. Usprawiedliwiający stosunek poszukuje przyczyn choroby w niekorzystnych czynnikach zewnętrznych. Chroni chorego, skłania do współczucia i zrozumienia. Częstsza postawa - piętnująca - utożsamia chorobę z karą za niewłaściwy tryb życia. Osoba chorująca może doświadczać odrzucenia, pozornego niezauważania, lekceważenia objawów, jawnej niechęci, wyrzutów, pretensji, obarczania winą i poczuciem wstydu za wystąpienie choroby. Najbliżsi skłonni są do odtrącenia, a nawet wykluczenia z grona rodziny bez okazania koniecznej pomocy i wsparcia.

Choroba dermatologiczna może być uznana za piętno przez samą osobę chorującą. Uświadomienie sobie jej istnienia jest szokiem i wymaga akceptacji nowego wizerunku, co ze względu na spadek poczucia własnej wartości nie jest łatwe. Wzmagające się i nawracające zmiany skórne powodują lęk, niepewność własnej przyszłości, dezaprobatę, wstyd. Zmuszają do kwestionowania swojego miejsca w otoczeniu. Reakcjami obronnymi na wzmagające się trudności wewnętrzne są: ironizowanie choroby, ukrywanie stanu zdrowia przed otoczeniem, zaprzeczanie istnieniu choroby, a z czasem częściowa lub całkowita izolacja społeczna (Rzepa, 2011), mająca negatywny wpływ na jakość życia chorującego człowieka.

2 Szerszy kontekst znaczenia terminu „piętno” w literaturze opisywali: E.E. Jones i in. (1984); J. Crocker, B. Major, C. Steele (1998); M.R. Hebl, R.E. Kleck (2000). 


\section{JAKOŚĆ ŻYCIA Z DERMATOLOGICZNĄ CHOROBĄ PRZEWLEKŁA}

Jakość życia oznacza ocenę dobrostanu człowieka, na który składają się między innymi stan zdrowia psychicznego, fizycznego oraz poziom funkcjonowania osoby w społeczeństwie (Szepietowski, Pacan, Reich, Grzesiak, 2012). Jakość relacji interpersonalnych uzależniona jest od wizerunku, na który składają się: wygląd skóry (zwłaszcza twarzy, szyi i rąk), rysy twarzy i mimika, wzrost, waga, sylwetka i postawa, kolor i jakość włosów (fryzura), stan uzębienia, zapach, ubiór i dodatki (kolorystyka, styl) (Skopińska, 2011). Na podstawie wyglądu skóry można ustalić wiek osoby, charakter wykonywanej przez nią pracy, typ osobowości i najczęściej przeżywane emocje, aktualny stan zdrowia oraz poziom ogólnej odporności (Rzepa, 2011). Zdrowa skóra poprawia samoocenę i poczucie własnej wartości, zmieniona chorobowo nie pozwala na dowolne kształtowanie własnego wizerunku, staje się przyczyną kompleksów i obniża jakość życia.

„Badania empiryczne nad jakością życia osób chorych dermatologicznie podjęto dopiero pod koniec lat 80.” (Janowski, 2007, s. 50). Powszechnie schorzenia skóry uznawane są za niezagrażające życiu i zdrowiu. Ich konsekwencje sprowadza się do problemów kosmetycznych, podczas gdy często stwarzają poważne, przewlekłe i nawracające problemy, dotyczące osób w różnym wieku. Największe obniżenie jakości życia wiąże się z atopowym zapaleniem skóry oraz łuszczycą (Szepietowski i in., 2012). Według doniesień Rappa, Feldmana, Exuma, Fleischera Jr. i Reboussina (1999) łuszczyca powoduje pogorszenie się jakości życia w aspekcie fizycznym w większym stopniu niż nowotwory złośliwe, cukrzyca lub zawał mięśnia sercowego. W badaniach przeprowadzonych przez Michalewską, Zawirską, Kwapisz i Adamskiego (2006) w 58\% badanych zmiany skórne w łuszczycy dotyczyły skóry całego ciała. Widoczne miejsca na głowie były zajęte zmianami chorobowymi u 38\% osób. Wszystkie osoby ankietowane stwierdziły, że łuszczyca obniżyła jakość ich życia, mając wpływ na życie zawodowe (70\%) poprzez ograniczenie tej aktywności lub utratę pracy. Osoby młode wskazywały, iż nieestetyczny wygląd skóry skłaniał je do unikania bezpośrednich kontaktów z otoczeniem, co miało negatywny wpływ na ich poziom edukacji, a także utrudniało znalezienie lub powodowało utratę potencjalnego partnera życiowego. Osoby pozostające w związkach małżeńskich musiały liczyć się z możliwością przekazania choroby własnym dzieciom (32\% dzieci osób ankietowanych chorowało na łuszczycę). Bardzo utrudniającym życie i dość powszechnym obciążeniem mogą być również takie schorzenia, jak: trądzik, opryszczka czy rzadziej występujące i opisywane w niniejszym opracowaniu łysienie plackowate, powodujące odrzucenie 0 zwłaszcza osób młodych - przez resztę społeczeństwa (Tuszyńska-Bogucka, 2007). 
Stopień nasilenia zmian skórnych, ich rozległość, lokalizacja i dynamika przebiegu choroby mają wpływ na bieg życia osób w różnym wieku, a w literaturze przedmiotu są rozpatrywane na trzech płaszczyznach: fizycznej, psychologicznej i społecznej (Janowski, 2007).

Fizyczny wymiar choroby skórnej sprowadza się do konsekwencji biomedycznych, które są następujące: duże trudności z osiągnięciem stanu całkowitego zejścia choroby, krótkie okresy remisji, niezadowalająca skuteczność podejmowanej terapii i uciążliwość jej stosowania (brudzące kremy lub maści o intensywnym zapachu; konieczność zmiany opatrunków), zbyt długi czas potrzebny na zabiegi higieniczne i lecznicze oraz odczucia subiektywne w postaci bólu, opuchlizny, podrażnienia, świądu, widocznej zmiany skóry pod względem jej struktury i barwy.

Choroba dermatologiczna dotyka również psychicznej sfery funkcjonowania człowieka. Bywa objawem niektórych zaburzeń pierwotnie psychiatrycznych (urojeniowych; zaburzeń obrazu ciała), schorzeniem modyfikowanym przez czynniki psychofizjologiczne (trądzik; łysienie plackowate; łuszczyca; atopowe zapalenie skóry) lub przypadłością o etiologii psychogennej (nadmierne pocenie się; przewlekła pokrzywka) (Korabel, Dudek, Jaworek, Wojas-Pelc, 2008). „Występowanie zaburzeń psychicznych wśród pacjentów dermatologicznych szacuje się na 30\% pacjentów leczonych ambulatoryjnie i 60\% hospitalizowanych” (Korabel i in., 2008, s. 244). Dane te dotyczą zarówno dzieci, jak i osób dorosłych. Do najczęściej obserwowanych nieprawidłowości natury psychiatrycznej w grupie osób chorujących dermatologicznie zalicza się zaburzenia nastroju o charakterze depresyjnym, zaburzenia lękowe, obsesyjne, urojeniowe i tendencje samobójcze. Wtórne zaburzenia psychiczne występujące w chorobach dermatologicznych modyfikowanych przez czynniki psychologiczne bardzo często występują na skutek stygmatyzacji, izolacji społecznej i pogorszenia się jakości życia. Choroba dermatologiczna powoduje utratę radości życia i satysfakcji z wypełnianych ról. Odbiera pewność siebie, sprawiając, że osoba ma niższe poczucie własnej wartości i nie potrafi odnaleźć sił do podejmowania zadań. Opisywana sytuacja ma miejsce szczególnie podczas kolejnych nawrotów, kiedy pojawia się poczucie niskiej atrakcyjności fizycznej, seksualnej, a chory martwi się ostatecznymi konsekwencjami swojej sytuacji. Widoczne dla otoczenia zmiany skórne przysparzają dodatkowych trudności. Ludzie ukradkiem przypatrują się defektom. Czują na ich widok dyskomfort, obrzydzenie, boją się, że choroba może być zaraźliwa. Osoba chora czuje się skrępowana. W niektórych przypadkach zażenowanie i wstyd mogą przekształcić się w stan bezradności, wycofania z kontaktów towarzyskich i życia zawodowego, rezygnację i depresję. 
Społeczny aspekt choroby dermatologicznej dotyczy, przede wszystkim, podstawowej dziedziny życia człowieka, jaką jest praca zawodowa. Choroba skórna wymusza podjęcie pracy respektującej charakterystyczny przebieg choroby. Niekiedy osoba chora jest zmuszona do częstszych zwolnień lub nawet rezygnacji z pracy zawodowej, a terapia dermatologiczna jest długotrwała i kosztowna. Choroba skóry może zakłócać stosunki interpersonalne, powodując konflikty. Jest ograniczeniem w zakresie form spędzania wolnego czasu (utrudnia dalekie podróże, uprawianie sportu, wychodzenie z domu, wymusza rezygnację z kąpieli i opalania). Ma wpływ na ograniczenia w zakresie korzystania z usług (fryzjer, kosmetyczka, manicure, pedicure) i dobór garderoby (wyłącznie ubrania zakrywające zmiany chorobowe, luźne; unikanie ciemnych kolorów przy zmianach łuszczycowych). Choroba dermatologiczna może utrudniać lub uniemożliwiać kontakty intymne. Ma negatywny wpływ na planowanie potomstwa. Stanowi ryzyko wystąpienia nałogów (Janowski, 2007).

\section{ATOPIA, ŁYSIENIE PLACKOWATE, ŁUSZCZYCA - SPECYFIKA ZABURZEŃ I ICH KONSEKWENCJE PSYCHOSPOŁECZNE}

Skóra jest największym narządem ludzkiego ciała. Powierzchnia tego organu u dorosłego człowieka wynosi od 1,5 do $2 \mathrm{~m}^{2}$, a jego grubość w zależności od lokalizacji waha się od 0,5 do $5 \mathrm{~mm}$. Łączy w sobie właściwości fizyczne i psychiczne człowieka. Jest organem czucia, wrażliwości, kształtuje naszą seksualność, ponieważ jest zespolona z układem nerwowym. Ma zdolność do wyrażania emocji. Podstawową funkcją skóry jest ochrona organizmu człowieka przed czynnikami fizycznymi, chemicznymi, biologicznymi i mechanicznymi, a także stanowienie połączenia ze środowiskiem zewnętrznym dzięki przepuszczalności naskórka. Skóra jest termoregulatorem, przez który odbywa się proces parowania i wnikania wody do organizmu. Może oddawać ciepło otoczeniu poprzez promieniowanie oraz przewodnictwo. Narząd ten jest magazynem znacznych ilości tkanki tłuszczowej, wody, sodu, potasu, magnezu i wapnia, a także witamin A, C, D oraz witamin z grupy B. W ciągu całego życia człowieka wygląd i struktura skóry zmieniają się. Różne są także jednostki chorobowe charakterystyczne dla określonego wieku (Orłowski, Kursa-Orłowska, Adamski, 2010).

Atopowe zapalenie skóry (AZS) zwane również świerzbiączką (dermatitis atopia, prurigo) jest chorobą, która rozpoczyna się w dzieciństwie (do 5. roku życia), a jej przebieg jest wieloletni. Charakteryzuje się występowaniem stanów zapalnych skóry z obecnością wykwitów wypryskowych. Częstość występowania 
AZS w populacji oceniana jest na 5-25\%. Jest to choroba genetyczna o bardzo złożonych i nie w pełni wyjaśnionych przyczynach. Zmiany skórne pojawiają się na skutek czynników alergicznych (wziewnych i pokarmowych) oraz niealergicznych - zwłaszcza środowiskowych (warunki klimatyczne; drobnoustroje), psychogennych i chemicznych (drażniące substancje).

Obraz zmian dermatologicznych u dzieci i osób dorosłych różni się. Niemowlęta doznają zmian wysiękowo-zapalnych w obrębie twarzy i skóry głowy. U dzieci w wieku przedszkolnym i szkolnym stan zapalny pojawia się w zgięciach łokciowych, kolanowych, okolicach nadgarstków, na skórze szyi i rąk. Młodzież i osoby dorosłe doznają zmian wypryskowych, które pojawiają się z okresowym zaostrzeniem w górnych partiach ciała. Skóra osób cierpiących na atopię jest nadmiernie wysuszona oraz podatna na nawracające zakażenia wirusowe i bakteryjne, co powoduje przewlekły świąd. To nieprzyjemne odczucie wzmaga się w kontakcie z wełnianymi tkaninami, podczas intensywnego pocenia się oraz w sytuacjach stresowych. Konsekwencją AZS jest przewlekłe alergiczne zapalenie błony śluzowej nosa (40-60\%), astma oskrzelowa (20-30\%), bóle brzucha (10\%) oraz zaćma atopowa (12\%), która powoduje poważne upośledzenie wzroku 25-50\% chorujących. O niekorzystnym przebiegu choroby można wnioskować wówczas, gdy dotyczy ona płci żeńskiej, rozpoczyna się we wczesnym dzieciństwie rozległymi zmianami skórnymi oraz współwystępuje z chorobami atopowymi górnych dróg oddechowych.

Leczenie atopowego zapalenia skóry polega na ustaleniu i wyeliminowaniu czynników, które zaostrzają objawy skórne. Nieodłączną i codzienną formą terapii oraz profilaktyki jest pielęgnacja skóry poprzez kąpiele z dodatkiem środków zmiękczających (emolientów) oraz jej natłuszczanie. Kąpiel nawadnia i złuszcza skórę, oczyszcza ją z alergenów, a środki zmiękczające nawilżają i uelastyczniają. Leczenie o charakterze medycznym polega na miejscowym podawaniu środków o silnym działaniu przeciwzapalnym oraz leków przeciwhistaminowych o działaniu ogólnym, a także antybiotyków. Ciężkie postacie atopowego zapalenia skóry są poddawane terapii promieniami ultrafioletowymi.

Psychologiczna sytuacja osób chorujących na AZS nieodłącznie związana jest z życiowymi wydarzeniami stresowymi. Czynnikiem nasilającym schorzenie u dzieci może być trudna sytuacja w rodzinie (rozwód rodziców, separacja, choroba członka rodziny) oraz zaburzenia emocjonalne lub zaburzenia zachowania. Osoby dorosłe częściej cierpią na stany lękowe i depresyjne. Objawy choroby powodują uporczywy świąd, skutkujący bezsennością, zmęczeniem i labilnością nastroju. Izolowanie się w sytuacjach społecznych bywa powodowane napiętnowaniem w środowisku rówieśniczym wśród dzieci i poczuciem wstydu w życiu człowieka 
dorosłego. Osoby chorujące na atopowe zapalenie skóry doświadczają ograniczeń w stylu życia (wybór odzieży, posiadanie zwierząt domowych, uprawianie sportu). W AZS lęk i depresja nasilają objawy choroby, a zaostrzone widoczne zmiany skórne wzbudzają lęk i powodują depresję, a więc jest to mechanizm negatywnego sprzężenia zwrotnego. Interwencja terapeutyczna w zakresie zdrowia psychicznego osoby polega na zastosowaniu psychoterapii, terapii behawioralnej, edukacji oraz leków psychotropowych (Levenson, 2008).

Społeczne konsekwencje atopowego zapalenia skóry dotyczą zwłaszcza rodzinnego i zawodowego trybu życia. AZS skutkuje obciążeniem budżetu rodzinnego, gdyż wymaga ponoszenia stałych wydatków na zalecane kosmetyki, środki piorące, leki, aparaturę wspomagającą leczenie oraz dostosowanie mieszkania do potrzeb chorego. Niejednokrotnie w rodzinie wielodzietnej problem alergii dotyczy więcej niż jednego dziecka, a ze względu na przebieg choroby pracę zawodową podejmuje tylko jeden rodzic. Choroba może mieć wpływ na pojawienie się niedostatku materialnego i zachwianie poczucia bezpieczeństwa członków rodziny. Alergia u dziecka kształtuje styl życia całej rodziny. Aspekt ten dotyczy ograniczania spędzania wolnego czasu na powietrzu w okresach intensywnego pylenia (alergia wziewna) czy kontaktów towarzyskich. Nie zawsze chore dziecko prawidłowo funkcjonuje w środowisku rówieśniczym. Czasem bywa izolowane i odrzucane z powodu widocznych zmian skórnych czy mniejszej sprawności fizycznej (Dworak, 2010). AZS, oprócz stałej troski, profilaktyki oraz leczenia przy okresowym nasileniu choroby, ma wpływ na zasadnicze wybory życiowe osoby chorującej. Do takich należy wybór drogi kształcenia i zawodu, w którym kontakt z drażniącymi czynnikami wywołującymi nawroty schorzenia będzie maksymalnie ograniczony (Samochocki, 2009). Najczęściej uczulającymi alergenami są proste związki chemiczne, takie jak: metale, substancje zapachowe, konserwanty kosmetyków i środków czystości, barwniki czy tworzywa sztuczne. Z takimi substancjami najczęściej mają do czynienia pracownicy ochrony zdrowia, farmaceuci, laboranci, technicy dentystyczni, pracownicy przemysłu kosmetycznego i perfumeryjnego, fryzjerzy i manikiurzystki, pracownicy przemysłu chemicznego, motoryzacyjnego, elektronicznego, budowlanego, rolno-spożywczego, metalurgicznego czy meblowego. Dla osób chorujących na AZS jednym z najważniejszych czynników drażniących pochodzenia zawodowego jest konieczność pracy w wilgotnym środowisku (konieczność częstego mycia rąk czy noszenia nieprzepuszczalnych rękawic). Warunkiem wykonywania zawodu przy jednoczesnym obciążeniu chorobą alergiczną skóry jest jej kontrola i skuteczne leczenie oraz świadome unikanie czynników alergicznych w pracy i domu, modyfikacja obowiązków na stanowisku pracy i używanie środków chroniących skórę przed podrażnieniem 
(używanie odzieży ochronnej oraz preparatów barierowych). Niekiedy stosowanie wymienionych środków zapobiegawczych nie skutkuje, a choroba utrzymuje się w sposób rozległy i nasilony. Wówczas konieczna bywa zmiana, ograniczenie w zakresie wykonywania określonego zawodu lub całkowita rezygnacja z pracy zawodowej na skutek częściowej lub całkowitej niezdolności do jej wykonywania (Chomiczewska, Kieć-Świerczyńska, Kręcisz, 2010).

Przypadek 1: Wojtek, 11 lat, dziecko cierpiące z powodu atopowego zapalenia skóry. Chorobę zdiagnozowano w 6. roku życia. Rozpoczęła się w okresie niemowlęcym zmianami skórnymi obecnymi na całym ciele, które nasilały się szczególnie w okresie zimowym. Po rozpoznaniu alergii wprowadzono zmiany dotyczące stosowanych kosmetyków i środków piorących. Używano ubrań wyłącznie z tworzyw naturalnych (bawełna, len, skóra). Zakupiono pościel antyalergiczną. Dokładnie stosowano się do zaleceń lekarza. Trudnym etapem w życiu chłopca było rozpoczęcie nauki w szkole z powodu odrzucenia przez wychowawcę i rówieśników. Wojtek nie został zaakceptowany w grupie. Posadzono go samotnie w ostatniej ławce. Nie proszono do tablicy. Wychowawczyni nie sprawdzała jego prac i zeszytów z powodu lęku przed zarażeniem się chorobą. Wojtek przestał ćwiczyć podczas lekcji wychowania fizycznego, ponieważ odmawiał przebrania się w krótkie spodenki i bluzkę z krótkim rękawem. Sytuacja w grupie rówieśniczej negatywnie wpłynęła na stan emocjonalny chłopca. Mimo informacji ze strony rodziców dziecka na temat postawionej diagnozy i specyfiki choroby chłopiec nie spotkał się ze zrozumieniem ze strony uczniów, ich rodziców, wychowawcy i pedagoga szkolnego. Konieczna okazała się zmiana szkoły (Dworak, 2010).

Łysienie plackowate jest jedną z chorób włosów, która dotyka 0,1-0,2\% populacji bez względu na dominację płci. Chorują przeważnie dzieci i osoby młode do 20. roku życia. Choroba pojawia się nagle w postaci ogniskowej utraty włosów. Przyczyna łysienia plackowatego nie jest do końca poznana. Współczesna etiopatogeneza wskazuje na autoimmunologiczne tło choroby, która często (do 52\% przypadków) występuje z atopowym zapaleniem skóry, bielactwem czy autoimmunologicznym zapaleniem tarczycy. Istotny jest także czynnik genetyczny (10-45\% osób chorych) o charakterze wielogenowym nie do końca poznanym, a także wpływ stresu na mechanizm wyzwalający chorobę u osób o biogenetycznej dyspozycji. Medycyna opisuje dwa typy łysienia plackowatego. Typ pierwszy charakteryzuje się wczesnym początkiem, częstym występowaniem rodzinnym, 
znaczną rozległością i opornością na zabiegi terapeutyczne. Typ drugi występuje u osób po 30. roku życia i częściej przybiera postać pojedynczych ognisk.

Wystąpienie choroby jest nagłe i szybko postępujące. W ciągu nawet kilku godzin osoba traci włosy, co ma postać jednego lub kilku owalnych ognisk. Szczególnie narażona jest część potyliczna, ale utrata włosów może dotyczyć całej powierzchni skóry głowy i ciała łącznie z wypadnięciem brwi i rzęs. W niektórych przypadkach zmiany dotyczą również paznokci. Łysienie plackowate jest przypadłością odwracalną. W 60\% przypadków włosy odrastają samoistnie w ciągu kilkunastu miesięcy, ale możliwe są nawroty choroby występujące co kilka miesięcy lub lat. Takiej sytuacji nie da się zapobiec ani jej przewidzieć. Niekorzystnie dla całkowitego zejścia choroby rokuje wczesna, rozległa, długo utrzymująca się i sprzężona z atopowym zapaleniem skóry postać choroby.

Leczenie łysienia plackowatego jest niespecyficzne i bywa niesatysfakcjonujące. Lekarze stosują terapię miejscową z wykorzystaniem kortykosteroidów (skutki uboczne; ryzyko nawrotu choroby po zakończeniu leczenia). W cięższych przypadkach praktykowane są naświetlania (fotochemoterapia), które stosuje się 2-3 razy w tygodniu przez wiele miesięcy (nawroty choroby po ustaniu naświetlań; ryzyko pojawienia się zmian nowotworowych). U dzieci najczęściej stosuje się miejscowe preparaty uczulające w postaci silnych alergenów kontaktowych (ryzyko wystąpienia niepożądanych następstw w postaci: wyprysku, rumienia, przebarwień, uogólnionego powiększenia węzłów chłonnych). Krioterapia, czyli mrożenie ognisk łysienia za pomocą ciekłego azotu, jest również metodą stosowaną w dawkach 2-3 razy w tygodniu w cyklach czterotygodniowych. Niekiedy osoba chorująca jest zmuszona poddać się zastrzykom podskórnym z leków steroidowych.

Istotnym czynnikiem psychologicznym indukującym wystąpienie łysienia plackowatego są stres, zaburzenia lękowe, zaburzenia nastroju, zaburzenia osobowości czy nieuświadomiony gniew. Szczególne znaczenie mają stresowe zdarzenia życiowe, które bywają czynnikiem wyzwalającym chorobę. Współwystępującymi zaburzeniami psychicznymi są zaburzenia adaptacyjne oraz epizody depresyjne, a u dzieci lęk, wycofanie się, agresja, zaburzenia somatyczne i problemy z adaptacją społeczną. Stosowane leczenie psychiatryczne i psychologiczne łysienia plackowatego sprowadza się do stosowania leków przeciwdepresyjnych oraz praktykowania psychoterapii oraz technik relaksacyjnych (Levenson, 2008; Sudnik, Żaba, 2011).

Łysienie plackowate jest chorobą o łagodnym przebiegu dla całego organizmu. Skóra nie zmienia koloru, a pacjentowi nie dokucza ból ani świąd. Jednak utrata włosów wpływa na całkowitą i niekorzystną zmianę wizerunku osoby, ponieważ identyfikowana jest z osłabieniem sił witalnych, brakiem atrakcyjności, siły, 
zaradności życiowej i sukcesu (Nowicka, Reich, Szepietowski, 2005). Łysienie zmienia jakość życia i sposób postrzegania siebie samego (utrata poczucia własnej wartości). Osoba odczuwa negatywne emocje: smutek, załamanie, wstyd, agresję i brak radości z życia. Otoczenie, w zetknięciu z nietypowym wyglądem osoby łysiejącej, często prezentuje: brak taktu, krytyczne postawy i słowa, natrętną ciekawość oraz współczucie. Kobieta, wraz z utratą włosów, traci swoją atrakcyjność, a mężczyzna czuje się mniej męski. Postawa wobec własnego wyglądu bywa negatywna, co skutkuje poczuciem niskiej atrakcyjności. Osoba obawia się niezrozumienia i braku akceptacji. Nie zawsze jest zadowolona z relacji z otoczeniem, wycofując się niekiedy z kontaktów społecznych. Rezygnacja z wchodzenia w relacje jest powodowana lękiem przed zdemaskowaniem choroby i może być barierą w realizacji zadań życiowych w środowisku rodzinnym, okolicznościach towarzyskich (relacje damsko-męskie, spędzanie wolnego czasu, realizacja zainteresowań) i zawodowych. Łysienie plackowate ma zatem istotny wpływ na kształtowanie kontaktów interpersonalnych, które są podstawą życia społecznego (Nowak i Pietras, 2013; Szymczak, 2018; Nadworna, 2018).

Osoby z rozległym łysieniem mogą poprawić swój wizerunek poprzez stosowanie peruk akrylowych oraz mikropigmentacji skóry głowy, a treski, sztuczne rzęsy i brwi, przedłużanie włosów, makijaż permanentny i tatuaże mogą być skutecznym rozwiązaniem w ukrywaniu utraty włosów (McLean, Tidman, 2013).

Przypadek 2: Wioleta, lat 7, łysienie skóry głowy po rozpoczęciu nauki w szkole. Dziewczynka adoptowana w 6. tygodniu życia. Rodzice adopcyjni zdystansowani emocjonalnie wobec siebie. Łącząca ich więź to przywiązanie i sprawy dotyczące dziecka. Dziewczynka straciła wszystkie włosy skóry głowy oraz rzęsy w wieku 4 lat. Włosy odrosły samoistnie. Wioleta dowiedziała się od koleżanki, że została adoptowana w wieku 5 lat. Rodzice nie zastosowali zasady jawności adopcji. Dziecko zaczęło stopniowo tracić włosy po rozpoczęciu nauki w zerówce. Badanie psychologiczne ujawniło trudności dziecka w radzeniu sobie z czynnikami stresującymi. Przyczyną stresu był wadliwy system rodzinny oraz trudności w relacjach z rówieśnikami. Zaburzenia wtórne do łysienia, manifestowane przez dziewczynkę, to: lęk, zamartwianie się, smutek. Rodzina konsekwentnie odmawiała poddania się psychoterapii rodzinnej (Sumiła, Cieślukowska, Pakalska-Korcala, 2009).

Łuszczyca (psoriasis) jest chorobą zapalną i niezakaźną. Występuje w trzech odmianach: zwyczajnej, krostkowej i stawowej. Jakość życia osób cierpiących z powodu łuszczycy znacznie pogarszają grudkowate czerwone wykwity skórne 
zajmujące nawet do 100\% powierzchni ciała, które w różnym stopniu pokryte są nawarstwionymi łuskami naskórka. Na łuszczycę choruje około 2\% osób populacji europejskiej we wszystkich grupach wiekowych, są to zarówno kobiety, jak i mężczyźni. Pierwszy typ łuszczycy, pojawiający się do 40. roku życia, objawia się rozległymi zmianami, krótkimi remisjami i częstszym występowaniem u rodzeństwa. W typie drugim początek choroby następuje około 55. roku życia, a indukowany jest czynnikami środowiskowymi.

Podstawowy czynnik etiologiczny pozostaje w łuszczycy nieznany. Obserwacje wskazują, że może być to choroba uwarunkowana genetycznie o wielogenowym i nieregularnym dziedziczeniu, co oznacza, że zdrowym rodzicom może urodzić się dziecko cierpiące na to schorzenie (60\% przypadków). Gdy jedno z rodziców choruje na łuszczycę, ryzyko jej wystąpienia u dziecka wynosi 10-20\%, jeżeli oboje - ryzyko to wzrasta do 50\%. W badaniach przeprowadzonych wśród bliźniąt wykazano, że współczynnik zgodności wystąpienia łuszczycy wynosił około 75\% bliźniąt monozygotycznych i około 25\% u bliźniąt dizygotycznych (Kosmala, Jenerowicz, Adamski, 2016). Patomechanizm występujący w obrębie skóry polega na zwiększonej proliferacji keratynocytów (zdolności namnażania komórek naskórka), co powoduje nierównomierny przerost naskórka, ścieńczenie lub zanik warstwy ziarnistej i niepełne rogowacenie komórek warstwy rogowej. Wystąpienie oraz kolejne nawroty łuszczycy są powodowane: ostrymi lub przewlekłymi infekcjami, stresem (stresogenne czynniki środowiskowe: palenie papierosów, hałas, niewłaściwa dieta, choroby i urazy, stres psychiczny), zmianami hormonalnymi okresu pokwitania, ciąży, menopauzy, urazami mechanicznymi powodującymi pojawienie się zmian zapalnych (wynikającymi nawet z zadrapań lub ucisku bielizny) oraz czynnikami środowiskowymi (alkohol, niektóre leki).

Zaczerwienione, łuszczące się zmiany na skórze mogą mieć różną wielkość. Rzadko występują na twarzy, ale dotyczą wszystkich pozostałych części ciała. U osób z mniej nasilonymi zmianami występują na łokciach i kolanach. W cięższych przypadkach obejmują do 100\% powierzchni skóry głowy, zewnętrzne przewody słuchowe, paznokcie i narządy płciowe. Łuszczyca jest chorobą nawracającą. Rytm nawrotów charakterystyczny jest dla każdej osoby chorującej (zazwyczaj dwa razy do roku). Wykwity pojawiają się zwykle w tych samych lokalizacjach, pozostawiając odbarwienia. Choroba może trwać wiele lat, nie mając wpływu na długość życia, ale stanowiąc poważne obciążenie fizyczne i psychiczne. Łuszczyca stawowa może prowadzić do trwałych zniekształceń w obrębie małych i dużych stawów, powodując trwałe zniekształcenia i niepełnosprawność ruchową.

Leczenie łuszczycy jest procesem wieloletnim, który wymaga terapii o charakterze miejscowym. Lekarze, ze względu na nasilenie i umiejscowienie zmian, 
zalecają stosowanie preparatów dziegciowych, klasycznych leków przeciwłuszczycowych (Cygnolina), kortykosteroidów, pochodnych witaminy $\mathrm{D}_{3}$, pochodnych witaminy A, naświetlań promieniami UVB, naświetlań metodą PUVA (wspólne działanie doustnych preparatów o silnych właściwościach fototoksycznych psoralenów oraz aktywujących wspomniane preparaty długich promieni UVA), leków o silnym działaniu immunosupresyjnym czy leków biologicznych. Zmiany łuszczycowe mogą również ustąpić samoistnie. Najczęściej ma to miejsce w okresie letnim, najprawdopodobniej pod wpływem światła słonecznego (Wolska, 2009).

Łuszczyca jest chorobą dermatologiczną o podłożu psychicznym. Pociąga za sobą poważne konsekwencje psychologiczne w postaci niskiej samooceny, lęku, depresji, aż do tendencji suicydalnych na tle negatywnego odbioru własnego wizerunku (Wiśniewska, Różewicka-Czabańska, Stocka, Ossowska-Kreft, Ertmański, Marchlewicz, Maleszka, 2016). Terapia medyczna powinna być uzupełniana zajęciami z psychoterapii, których celem jest osiągnięcie stabilnej i satysfakcjonującej pozycji psychicznej oraz społecznej przez osobę chorującą. Cenna jest również inicjatywa w postaci grup wsparcia redukujących tendencje do izolacji społecznej oraz wzmacniających mechanizmy radzenia sobie z chorobą (Korabel, Dudek, Jaworek, Wojas-Pelc, 2008). James L. Levenson (2008) opisywał również zastosowanie technik medytacyjnych, hipnozy, treningu relaksacyjnego, treningu autogennego oraz metod poznawczo-behawioralnych ograniczających stres, które były wykorzystane w terapii psychologicznej łuszczycy. Jedną z metod odsunięcia osoby chorującej od stresu była również hospitalizacja (Miękoś-Zydek, Ryglewska-Cho, Lassota-Falczewska, Czyż, Kaszuba, 2006).

Łuszczyca ujemnie wpływa nie tylko na funkcjonowanie psychiczne, ale również społeczne (stygmatyzacja, odrzucenie), zawodowe (problemy z zatrudnieniem) i somatyczne osoby chorującej (Lovenson, 2008). Widoczne, rozległe obszary skóry zajęte zmianami chorobowymi są przyczyną powstawania zaburzeń interpersonalnych w relacjach o charakterze osobistym i społecznym. Konieczność stosowania maści przeciw łuszczycowych (cignolina) powoduje u osób chorujących uczucie bycia nieczystym, ponieważ lek ma brunatną barwę, tłustą konsystencję i nieprzyjemny zapach. Nasilone objawy choroby i skutki uboczne leczenia powodują zahamowania w zakresie życia intymnego. Osoba chorująca na łuszczycę nosi w sobie poczucie skazy, winy i wstydu. Czuje się zakłopotana przebywając w towarzystwie, sądząc, że wszyscy przyglądają się objawom choroby, wyrażają swoje opinie i okazują w sposób nieszczery pozytywne nastawienie (Miękoś-Zydek, Ryglewska-Cho, Lassota-Falczewska, Czyż, Kaszuba, 2006). Z pewnością łuszczycowe zmiany skórne powodują utrudnienia w zawieraniu i utrzymywaniu relacji międzyludzkich, prowadząc do izolacji i poczucia stygmatyzacji (Lovenson, 
2008; Wiśniewska, Różewicka-Czabańska, Stocka, Ossowska-Kreft, Ertmański, Marchlewicz, Maleszka, 2016). Wiele osób czuje się skrępowanych swoją chorobą, wykonując codzienne czynności zawodowe lub spędzając czas wolny. Osoba chora na łuszczycę często jest zmuszona do rezygnacji z uprawiania sportu (pływanie), opalania się, kupowania odzieży (obawa przed przymierzaniem), wizyt u fryzjera czy nawet korzystania z publicznych środków transportu. Dodatkowe schorzenia somatyczne współwystępujące z łuszczycą, a są nimi schorzenia i zaburzenia metaboliczne (choroba Crohna, wrzodziejące zapalenie jelit, otyłość) i schorzenia układu sercowo-naczyniowego (Wolska, 2009) oraz powikłania związane ze stosowanymi formami terapii medycznej (podrażnienia i przebarwienia skóry, świąd, przedwczesne starzenie się skóry) (Miękoś-Zydek, Ryglewska-Cho, Lassota-Falczewska, Czyż, Kaszuba, 2006) dodatkowo obciążają sytuację zdrowotną osoby, utrudniając jej funkcjonowanie osobiste i społeczne.

Przypadek 3: Dwie siostry 6- i 10-letnia zostały przyjęte do Kliniki Dermatologii w Poznaniu z powodu wystąpienia objawów łuszczycy pospolitej. U młodszej dziewczynki pierwsze objawy choroby pojawiły się po streptokokowej infekcji gardła. Starsza zachorowała cztery miesiące później bez wyraźnej przyczyny. Dodatkowo stwierdzono u niej alergię wziewną oraz krótkowzroczność. Rodzice dziewczynek nie chorowali na łuszczycę. Choroba jednak była obecna w rodzinie - u brata ojca dziewczynek rozpoznano łuszczycę. Rumieniowe zmiany skórne pokryte łuską były u dzieci zlokalizowane w obrębie owłosionej skóry głowy, okolicy czołowej, na plecach, klatce piersiowej, brzuchu oraz kończynach górnych i dolnych. Wykwitom towarzyszył świąd (Kosmala i in., 2016).

\section{ZAMIAST ZAKOŃCZENIA. WSPARCIE SPOŁECZNE W SCHORZENIACH DERMATOLOGICZNYCH - PRZYKŁAD (NIE)OBECNOŚCI ORGANIZACJI POZARZĄDOWYCH W PRZESTRZENI PUBLICZNEJ}

Przewlekła choroba dermatologiczna wywiera istotny wpływ na funkcjonowanie psychiczne oraz kontakty społeczne osoby chorującej, co może skutkować poczuciem stygmatyzacji i wykluczenia z różnych sfer życia społecznego. Zaburzeniami psychicznymi, na które częściej cierpią osoby z chorobami skóry niż osoby zdrowe, są: lęk, depresja czy neurotyzm. Wymienione niekorzystne stany psychiczne są nie tylko skutkiem samej choroby, ale również występujących postaw społecznych i niezrozumienia otoczenia w odpowiedzi na objawy, konieczność długotrwałego 
i kłopotliwego leczenia oraz postawy samych osób chorujących, które sprowadzają się do poczucia zawstydzenia i odtrącenia, zwłaszcza podczas kontaktów w miejscach publicznych. Istotnym składnikiem życia osobistego i społecznego jest praca zawodowa. Dla osób cierpiących na niektóre schorzenia dermatologiczne ważną kwestią jest wybór kierunku kształcenia zawodowego i charakter wykonywanych czynności zawodowych, ponieważ rodzaj pracy może mieć wpływ na zaostrzenie się choroby. Środowisko zawodowe może być również miejscem stwarzającym obawy przed niechęcią ze strony współpracowników. Dodatkowym obciążeniem jest także okresowa absencja spowodowana koniecznością wdrożenia odpowiedniego leczenia, które wiąże się z wysokimi kosztami dla pacjentów. Choroba skóry powoduje cierpienie osoby chorującej i dezorganizuje jej życie rodzinne poprzez: nierównomierny podział obowiązków pomiędzy małżonkami, pojawienie się lęku o przyszłość i następstwa choroby u współmałżonka, istniejące ograniczenia w zakresie spędzania wolnego czasu czy stwarzanie bariery w kontaktach intymnych (Tyc-Zdrojewska, Trznadel-Grodzka, Kaszuba, 2011).

Silne poczucie stygmatyzacji u osób chorujących dermatologicznie powodowane jest negatywnymi reakcjami otoczenia, któremu brakuje wiedzy na temat przebiegu i skutków opisywanych schorzeń. W badaniach J. Chodkiewicz, I. Haduch, T. Hawro, J. Miniszewskiej, A. Sysa-Jędrzejowskiej i A. Zalewskiej-Janowskiej (2008) wykazano tymczasem istotną korelację pomiędzy wsparciem społecznym a ogólnym stanem zdrowia osób chorujących dermatologicznie. Jakość życia i adaptacja tych pacjentów byłyby lepsze, gdyby zyskali oni wyraźny wizerunek społeczny o jasno określonych potrzebach. Podmiotami, których działalność mogłaby sprostać temu zadaniu, są organizacje pozarządowe, które realizują cele związane z profilaktyką zdrowotną, pedagogizacją oraz integracją społeczną osób niepełnosprawnych i chorujących przewlekle - również dermatologicznie.

W Polsce w 2015 roku zarejestrowano 86 tys. stowarzyszeń i 17 tys. fundacji, czyli łącznie około 100 tys. organizacji (Piotrowicz, Cianciara, 2013b; Adamiak, Charycka, Gumkowska, 2016). Podmioty, dla których „ochrona zdrowia” stała się głównym obszarem działania, stanowiły 5,3 tys. (6-8\%) wszystkich aktywnych organizacji społecznych (Charycka, 2017). Zazwyczaj łączyły one cele zdrowotne z „edukacją i wychowaniem” oraz „usługami socjalnymi i pomocą społeczną”. Większość organizacji nonprofit znajdowała się w dużych miastach (największe zagęszczenie na terenie województwa mazowieckiego; najmniejsze w województwie świętokrzyskim). Głównymi obszarami ich działalności było dostarczanie świadczeń (medycznych i socjalnych, psychologicznych i integracyjnych, opiekuńczo-pielęgnacyjnych, rzeczowych i finansowych) oraz rzecznictwo zdrowotne (lobbing na rzecz modyfikacji aktów prawnych, spotkania publiczne, 
udział w konsultacjach społecznych, budowanie koalicji z innymi organizacjami, współpraca z mediami) (Piotrowicz, Cianciara, 2013a). Do zadań szczegółowych tych organizacji należały: promocja zdrowia, profilaktyka i edukacja zdrowotna (73\%); rehabilitacja i terapia (prowadzenie lub wsparcie finansowe) (60\%); interwencja kryzysowa i wsparcie psychologiczne (30\%); dystrybucja leków, materiałów i sprzętu medycznego (29\%); opieka szpitalna, ambulatoryjna i badania medyczne (14\%) oraz ratownictwo medyczne (5\%) i krwiodawstwo (3\%) (Charycka, 2017).

W obszarze usług zdrowotnych funkcjonowało szereg rodzajów organizacji społecznych mających charakter: organizacji międzynarodowych (globalne problemy zdrowotne), stowarzyszeń specjalistów, organizacji promujących określone kwestie zdrowotne (np. aktywność fizyczną), organizacji instytucji ochrony zdrowia, interesów określonych grup społecznych oraz organizacje pacjenckie (reprezentujące zdrowotne i socjalne potrzeby określonych grup osób chorujących lub niepełnosprawnych). Liczba tych ostatnich kształtowała się na poziomie 1 tys. organizacji (Charycka, 2017). Według bazy organizacji działających na rzecz pacjentów z różnymi chorobami i zaburzeniami stworzonej przez Instytut Praw Pacjenta i Edukacji Zdrowotnej w Polsce największą grupę stanowiły organizacje działające w dziedzinie: onkologii, neurologii, psychiatrii, immunologii, genetyki i diabetologii. Innymi istotnymi dziedzinami były: rehabilitacja, reumatologia oraz alergologia.

Najistotniejszym przymiotem organizacji społecznych działających w obszarze ochrony zdrowia, a więc również osób chorujących dermatologicznie i ich rodzin, było popularyzowanie wiedzy na temat konkretnej choroby w kwestii profilaktyki i sposobów leczenia. Niezwykle ważną aktywność stanowiło udzielanie wsparcia psychologicznego oraz tworzenie grup samopomocowych (Twardowski, 1995; Charycka, 2017), które skupiały osoby chore, ich bliskich, osoby zagrożone chorobą oraz lekarzy i personel medyczny. Pomocą dla beneficjentów był także zakup leków, sprzętu medycznego, organizacja rehabilitacji oraz opieki długoterminowej i organizacja zbiórek publicznych na rzecz konkretnych osób.

Tymczasem, według zasobów bazy danych o organizacjach pozarządowych Stowarzyszenia Klon/Jawor³ , w Polsce działało 19 organizacji osób chorujących na łuszczycę (najwięcej - 10 w woj. dolnośląskim) oraz 2 organizacje wspomagające osoby z atopowym zapaleniem skóry (woj. dolnośląskie; woj. mazowieckie). Nie zarejestrowano żadnego podmiotu zajmującego się problematyką łysienia

3 bazy.ngo.pl/chorzy (data dostępu: 26.04.2018) 
plackowatego ${ }^{4}$. Przytoczone fakty nasuwają przypuszczenie, że środowiska osób chorujących dermatologicznie nie są dostatecznie reprezentowane w przestrzeni publicznej, dlatego niewiele wiemy o przyczynach, skutkach, objawach oraz częstości występowania rzadkich przewlekłych chorób skóry, a pacjenci żyją w poczuciu niezrozumienia i niekiedy odtrącenia.

\section{Bibliografia}

Adamiak, P., Charycka, B., Gumkowska, M. (2016). Kondycja sektora organizacji pozarzq̨dowych w Polsce 2015. Raport z badań. Warszawa: Stowarzyszenie Klon/Jawor. Pobrane z: http://fakty.ngo.pl/wiadomosc/1912424.html.

Broda-Wysocki, P. (2012). Wykluczenie i inkluzja społeczna. Paradygmaty i próby definicji. Warszawa: Instytut Pracy i Spraw Socjalnych.

Charycka, B. (2017). Organizacje pacjentów w Polsce. Struktura, aktywności, potrzeby. Raport z badań 2017. Warszawa: Instytut Praw Pacjenta i Edukacji Zdrowotnej; Stowarzyszenie Klon/Jawor. Pobrane z: http://www.ippez.pl/raporty/.

Chodkiewicz, J., Haduch, I., Hawro, T., Miniszewska, J., Sysa-Jędrzejowska, A., Zalewska-Janowska, A. (2008). Wsparcie społeczne a ogólny stan zdrowia psychicznego chorych na łuszczycę. Dermatologia Kliniczna, 10(1), s. 9-13.

Chomiczewska, D., Kieć-Świerczyńska, M., Kręcisz, B. (2010). Choroby alergiczne skóry. W: M. Kieć-Świerczyńska, C. Pałczyński (red.), Jak żyć i pracować z chorobq alergicznq? (s. 21-53). Łódź: Oficyna Wydawnicza Instytutu Medycyny Pracy im. prof. J. Nofera.

Davidio, J.F., Major, B., Crocker, J. (2008). Piętno: wprowadzenie i zarys ogólny. W: T.F. Heatherton, R.E. Kleck, M.R. Hebl, J.G. Hull (red.), Społeczna psychologia piętna (s. 23-45). Warszawa: Wydawnictwo Naukowe PWN.

Dubisz, S. (red.). (2003). Uniwersalny Słownik Języka Polskiego. Tom 2. Warszawa: Wydawnictwo Naukowe PWN.

Dworak, A. (2010). Jakość życia dziecka z alergiq. Uwarunkowania środowiska rodzinnego. Toruń: Wydawnictwo Edukacyjne Akapit.

Goffman, E. (2005). Piętno. Rozważania o zranionej tożsamości. Gdańsk: Gdańskie Wydawnictwo Psychologiczne.

Grzegorczyk, L. (1974). Epidemiologia chorób zawodowych skóry. Warszawa: Państwowy Zakład Wydawnictw Lekarskich.

Janowski, K. (2007). Problematyka jakości życia w chorobach dermatologicznych. W: S. Steuden, W. Okła (red.), Jakość życia w chorobie (s. 49-62). Warszawa: Wydawnictwo KUL.

Korabel, H., Dudek, D., Jaworek, A., Wojas-Pelc, A. (2008). Psychodermatologia: psychologiczne i psychiatryczne aspekty w dermatologii. Przegląd Lekarski, 65(5), s. 244-248.

Kosmala, A., Jenerowicz, D., Adamski, Z. (2016). Opis przypadku łuszczycy pospolitej

${ }^{4}$ W Internecie można znaleźć dostęp do strony jedynej Fundacji „Łysienie Plackowate”. 
u sióstr - domniemana rola czynników genetycznych, zakaźnych oraz stresu w powstawaniu choroby. Dermatologia Praktyczna, 8(3), s. 53-58.

Levenson, J.L. (2008). Problemy psychiatryczne w dermatologii. Część 1. Atopowe zapalenie skóry i łuszczyca. Psychiatria po Dyplomie, 5(6), s. 77-80.

Levenson, J.L. (2008). Problemy psychiatryczne w dermatologii. Część 2. Łysienie plackowate, pokrzywka i obrzęk naczynioruchowy. Psychiatria po Dyplomie, 5(6), s. 81-83.

McLean, K.J., Tidman, M.J. (2013). Łysienie plackowate: problem głębszy niż skóra. Lekarz Rodzinny, 12, s. 828-832.

Michalewska, A., Zawirska, A., Kwapisz, R., Adamski, Z. (2006). Ocena wpływu łuszczycy na chorego i środowisko, w jakim żyje - badania wstępne. Polski Przeglq̨d Nauk o Zdrowiu, 4, s. 273-276.

Miękoś-Zydek, B., Ryglewska-Cho, A., Lassota-Falczewska, M., Czyż, P., Kaszuba, A. (2006). Jakość życia pacjentów z łuszczycą. Postępy Dermatologii i Alergologii, 23(6), s. 273-177.

Nadworna, S. (2018). Łysienie plackowate. Życie pełne wyzwań. Książka powstała w inteligentnym systemie wydawniczym Ridero.

Nowak, K., Pietras, J. (2013). Jakość życia po przeszczepie włosów na przykładzie pacjentów Kliniki AM - MED we Wrocławiu. Legnica: Wyższa Szkoła Medyczna w Legnicy.

Nowicka, D., Reich, A., Szepietowski, J. (2005). Psychologiczne aspekty androgenowego łysienia męskiego. Dermatologia Kliniczna, 7(1), s. 35-36.

Orłowski, M., Kursa-Orłowska, J., Adamski, Z. (2010). Budowa prawidłowej skóry. W: Z. Adamski, A. Kaszuba (red.), Dermatologia dla kosmetologów (s. 3-10). Wrocław: Elsevier Urban \& Partner.

Pietras, J., Bogowska, M. (2017). Trq̨d dawniej i dziś. Legnica: Wyższa Szkoła Medyczna w Legnicy.

Piotrowicz, M., Cianciara, D. (2013). Rola organizacji pozarządowych w życiu społecznym oraz systemie zdrowotnym. Przegląd Epidemiologiczny. 67(1), s. 151-155.

Piotrowicz, M., Cianciara, D. (2013). Stowarzyszenia i fundacje działające w obszarze ochrony zdrowia i ich znaczenie w systemie zdrowotnym w Polsce. Przegląd Epidemiologiczny, 67(1), s. 145-149.

Rapp, S.R., Feldman, S.R., Exum, M.L., Fleischer, A.B. Jr, Reboussin, D.M. (1999). Psoriasis causes as much disability as other major medical diseases. Journal of the American Academy of Dermatology, 41, s. 401-407.

Rzepa, T. (2011). Choroby skóry jako niszczące piętno. W: T. Rzepa, J. Szepietowski, R. Żaba (red.), Psychologiczne i medyczne aspekty chorób skóry (s. 13-14). Wrocław: Cornetis.

Samochocki, Z. (2009). Choroby alergiczne skóry. W: M. Błaszczyk-Kostanecka, H. Wolska (red.), Dermatologia w praktyce (s. 66-82). Warszawa: Wydawnictwo Lekarskie PZWL.

Skopińska, S. (2011). Piękna skóra wyznacznikiem dobrego samopoczucia i akceptacji społecznej. W: T. Rzepa, J. Szepietowski, R. Żaba (red.), Psychologiczne i medyczne aspekty chorób skóry (s. 30-34). Wrocław: Cornetis.

Sudnik, W., Żaba, R. (2011). Choroby włosów. W: T. Rzepa, J. Szepietowski, R. Żaba (red.), Psychologiczne i medyczne aspekty chorób skóry (s. 136-150). Wrocław: Cornetis. 
Sumiła, A., Cieślukowska, A.M., Pakalska-Korcala, A. (2009). Psychodermatozy u dzieci - opis przypadku. W: K. Janowski, J. Gierus (red.), Człowiek chory - aspekty biopsychospołeczne (s. 389-398). Lublin: Centrum Psychologii i Pomocy Psychologicznej w Lublinie.

Szepietowski, J., Pacan P., Reich A., Grzesiak M., (2012). Psychodermatologia. Wrocław: Akademia Medyczna im. Piastów Śląskich.

Szymczak, M. (2018). Problem w głowie czy na głowie? Dowiedz się, z czym naprawdę walczysz! Warszawa: Staempfli Polska.

Śpiewak, R. (2012). Częstość występowania chorób skóry w losowej grupie dorosłych Polaków. Estetologia Medyczna i Kosmetologia, 2. Pobrane z: www.estetologia.pl/ art/emk2012-010.pdf.

Tuszyńska-Bogucka, W. (2007). Funkcjonowanie systemu rodziny z dzieckiem przewlekle chorym dermatologicznie. Lublin: Wydawnictwo UMCS.

Twardowski, A., (2008). Pomoc rodzinom dzieci niepełnosprawnych. W: I. Obuchowska (red.), Dziecko niepełnosprawne w rodzinie (s. 543-582). Warszawa: Wydawnictwa Szkolne i Pedagogiczne.

Tyc-Zdrojewska, E., Trznadel-Grodzka, E., Kaszuba, A. (2011). Wpływ przewlekłych chorób skóry na jakość życia pacjentów. Dermatologia Kliniczna, 13(3), s. 155-160.

Winogrodzki, G.R. (2017). Organizacje pozarzq̨dowe w systemie bezpieczeństwa państwa. Józefów: Wydawnictwo Wyższej Szkoły Gospodarki Euroregionalnej.

Wiśniewska, J., Różewicka-Czabańska, M., Stocka, A., Ossowska-Kreft, N., Retmański, S., Marchlewicz, M., Maleszka, R. (2016). Analiza stanu psychicznego pacjentów z łuszczycą plackowatą w odniesieniu do ciężkości choroby. Dermatologia Praktyczna, 8(1), s. 5-11.

Wolska, H. (2009). Łuszczyca i choroby z jej kręgu. W: M. Błaszczyk-Kostanecka, H. Wolska (red.), Dermatologia w praktyce (s. 126-137). Warszawa: Wydawnictwo Lekarskie PZWL.

Wolska, H. (2009). Łuszczyca. Warszawa: Wydawnictwo Lekarskie PZWL.

World Health Organization (2014). Global status report on noncommunicable diseases 2014. WHO: Switzerland. Pobrane z: http://www.who.int/topics/chronic_diseases/en/. Ziarko, M. (2014). Zmaganie się ze stresem choroby przewlekłej. Poznań: Wydawnictwo Naukowe Wydziału Nauk Społecznych UAM. 